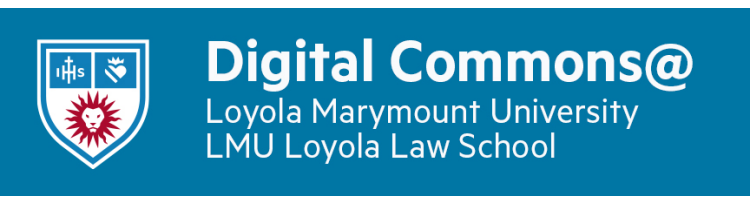

Journal of Catholic Education

\title{
The Generation to Come: Lutheran Education in the United States
}

John Isch

Follow this and additional works at: https://digitalcommons.Imu.edu/ce

\section{Recommended Citation}

Isch, J. (2002). The Generation to Come: Lutheran Education in the United States. Journal of Catholic

Education, 5 (4). http://dx.doi.org/10.15365/joce.0504082013

This Focus Section Article is brought to you for free with open access by the School of Education at Digital Commons at Loyola Marymount University and Loyola Law School. It has been accepted for publication in Journal of Catholic Education by the journal's editorial board and has been published on the web by an authorized administrator of Digital Commons at Loyola Marymount University and Loyola Law School. For more information about Digital Commons, please contact digitalcommons@lmu.edu. To contact the editorial board of Journal of Catholic Education, please email JCE@nd.edu. 


\section{THE GENERATION TO COME: LUTHERAN EDUCATION IN THE UNITED STATES}

\section{JOHN ISCH}

\section{Martin Luther College}

After a brief look at the historical origin of Lutheran education, this article provides an overview of contemporary Lutheran schools, educational philosophy, and future trends. The history, structure, and struggles of Lutheran education share many elements with Catholic education.

A long time ago two men taught the German Lutherans an important lesson about the church's responsibility for Christian education. These two men, who were neither Lutheran nor German, managed to irritate the German Lutherans and the German Catholics of Wisconsin as no two men have done before or since (W. Schmidt, 1968; Ulrich, 1980).

Michael John Bennett was a 28-year-old Catholic farmer and schoolteacher from the charming southwestern Wisconsin hamlet of Pine Knot. In 1888 , he was an assemblyman as well as chairman of the education committee of the Wisconsin legislature. A bill, which quietly passed the assembly and senate in Madison, became the Bennett Law in 1889. The Bennett Law restricted child labor, required children to attend school for at least 12 weeks of the year, and dictated that some of the classes must be taught in English (W. Schmidt, 1968; Ulrich, 1980).

The bill was signed by the second person in our cautionary tale, Governor William Dempster Hoard. Before being elected governor in 1888, Hoard had been the editor of Hoard's Dairyman. Hoard, a dynamic speaker much in demand in Wisconsin, was an energetic promoter of the dairy business, particularly the newly introduced cheese-making industry. His champion was the humble dairy cow. One of his oft-quoted sayings was, "Speak to a cow as you would to a lady." His biography was dedicated to "every man who follows in the footsteps of a dairy cow" (Ulrich, 1980, p. 134). And he was a Yankee, a derogatory term applied to anyone who was a native-English speaker (W. Schmidt, 1968; Ulrich, 1980). 
Several months after the Bennett Law went into effect, the residents of Wisconsin, particularly the Lutherans and the Catholics, became aware of the content and implications of the law. The Democrats, who were out of power, sensed a juicy political issue and their newspaper, the Milwaukee Journal, told the good citizens of Wisconsin what the Bennett Law would mean for parochial schools. The German language newspapers quickly picked up the story and soon the Germans condemned the Bennett Law as a vicious attack on their language, their religion, and their parochial schools. A rally cry, protesting the requirement to teach arithmetic in English, became "Zwei und Zwei machen Vier [Two plus two equals four]" (W. Schmidt, 1968; Ulrich, 1980).

In the Lutheran and Catholic parochial schools, teachers who knew little English taught all subjects in German. The Germans were proud to be Americans, but they were prouder to be Germans. They believed that if their children lost the mother tongue, they would also lose their religion, their culture, and even their ability to communicate with their parents. The battle over the Bennett Law became a battle for the rights of parents against the oppressive interference of the state. It was a classic battle of good versus evil, at least as the Democrats and the German-language newspapers characterized it.

Governor Hoard, a Republican, stoutly defended the law he had signed. When the Milwaukee Journal attacked him and the legislature, the governor, who seemed to have a particular ineptness when it came to the use of animal metaphors, replied, "Wisconsin is the dog and Milwaukee is the tail and this is one case where the tail is not going to wag the dog" (Ulrich, 1980, p. 183).

The Republicans and the governor never had a chance. In the fall elections of 1890 the Democrats took the governorship, both houses of the state legislature, the U.S. Senate seat, and eight of the nine House of Representatives seats. One month after the new legislature met in Madison, they repealed the Bennett Law. Ex-governor Hoard left Wisconsin for an extended speaking tour in the U.S. on his favorite topic: the noble qualities of the dairy cow. Assemblyman Bennett retired to the more quiet life in Pine Knot (Ulrich, 1980).

As the 19th century drew to a close, the German Lutherans faced a crisis in their programs of Christian education, particularly the parochial school. When the Bennett Law was passed, the churches became heavily involved in the political activities of 1889 to repeal the law. Lutherans joined Catholics in sponsoring resolutions, collecting money, holding sauerkraut rallies, and denouncing Governor Hoard and the public school people in Wisconsin. Professors from Lutheran colleges spoke around the state urging the citizens to elect a legislature which would repeal the Bennett Law and be more responsive to the concerns of parents and churches. Lutheran clergymen called on Governor Hoard and asked him not to enforce the law.

And the Germans, Catholic and Lutheran, won. But it was a strange vic- 
tory. In a few years, most of those same German parochial schools included English in their curriculum and instruction. Germans complied with the Bennett Law shortly after the law had been repealed. Some writers (Fredrich, 1992; W. Schmidt, 1968) on the history of Lutherans and Lutheran schools have commented that the Lutheran church had been forced by the Bennett Law controversy to take a hard look at its Christian education and ask, "Why?" When the congregations fought to preserve their parochial schools, they also had to ask why they were willing to fight. These congregations realized that language was not the main issue. They knew that their children spoke German in the classroom but spoke English on the playground. What really mattered was the free proclamation of the gospel, and that included the rights and the responsibilities of parents and congregations. Essays and articles began appearing which gave a new meaning to the forms and functions of Christian education.

One also suspects that communication between parents and children did not break down because the children were taught in English in the parochial school; there are certainly other reasons why parents and children do not communicate well. Perhaps the Bennett Law helped parents and schoolteachers understand better how truly complementary all agencies of Christian education must be. There ought to be a wholeness to Christian education whereby parents, Lutheran school teachers, Sunday school teachers, and pastors share the same responsibility and have the same goals for nurturing children.

One should not place too much emphasis on the Bennett Law, although it is interesting history. The Bennett Law was not the first (nor the last) time the German Lutherans had faced the issue of what it means to be GermanAmerican and what place the German language and culture had in the faith, life, education, and worship of Lutherans.

The story, however, does provide a backdrop for the limitations of this discussion of Lutheran education. First, this discussion will focus on schools, but education is more than a German grade school. Education is an allencompassing, pervasively present activity. When the Lord spoke in Deuteronomy, he began with the great Shema: "Hear O Israel, the Lord our God, the Lord is one." God then described how the teaching of his truth was to be done: "These commandments that I give you today are to be upon your hearts. Impress them on your children. Talk about them when you sit at home and when you walk along the road, when you lie down and when you get up. Tie them as symbols on your hands and bind them on your foreheads. Write them on the doorframes of your houses and on your gates" (Deut. 6:6-9). This is education in its broadest form.

Second, this discussion is also limited because in addition to its schoolroom focus, it deals specifically with the German Lutherans. The Scandinavians who also immigrated to the United States in the 19th century 
came from a society that supported schools that included Lutheran instruction. When they came to the United States, however, they generally did not establish their own parochial schools as did the Germans. Norwegian theologian Georg Sverdrup (1848-1907) was particularly influential in convincing the Norwegians and the immigrants from other Scandinavian countries that public schools in the United States were appropriate for the children of the immigrants and these schools were often preferable to Lutheran schools (Hamre, 1965, 1995). Using both Scripture and the writings of Luther, Sverdrup argued that establishing a separate Lutheran school system in this country would violate the separation of church and state and would result in a loss of freedom and independence of the church. Madson (n.d.) also suggested that the desire to preserve a language and culture might not have been as strong among the Norwegians as it was among the Germans. At least one historian (Beck, $1931 / 1965$ ) suggested that pastors among the Scandinavians were less willing to serve as teachers when regular teachers were unavailable, which in turn hampered the establishment of schools. In any case, those Lutheran church bodies that grew out of the Scandinavian immigrations were less likely to have Lutheran elementary or secondary schools. The Scandinavians, however, did establish notable liberal arts colleges whose names still stand for quality education and also retain considerable pride in their Scandinavian heritage. Burtchaell (1998) describes the founding, growth, and eventual separation from the church body of these Lutheran colleges.

\section{A BRIEF HISTORY}

Germans came to the United States in large numbers during the latter half of the 19th century. German immigration reached its peak between 1880 and 1890. Various estimates put the number of German immigrants at five million with two-thirds of them Lutheran/Reformed and one-third Catholic.

Most of these Germans held different beliefs in relation to the importance of language and culture than the Scandinavians. When Germans immigrated to this country and began their parish school system, the use of German as the medium of instruction was more than a cultural choice. German was the language of their religion and their confessions. Their namesake, Martin Luther, had repeatedly and passionately preached the case for the establishment of schools that would train children and youth in both religion and culture. Their Bible, translated by Luther, was German and the language of God. Their great hymnody was German, the catechism was German, and their church liturgy was German. The pastors who came with the Germans saw their mission field among the German immigrants. To many it was incomprehensible that they could worship without German. The immigrants feared that they might lose their confessional heritage if they lost the German language.

But there were also among the German immigrants persons who asked 
questions about the need and purpose of German Lutheran schools. J.C.W. Lindeman, the president of a Lutheran teacher training institution, in 1865 urged the inclusion of English as a subject in the parochial school: "Our children are estranged from the people among whom they live if they do not learn the English language," and "If we do not offer the necessary instruction in English, parents may be inclined to send their children to public schools" (as cited in Stellhorn, 1963, p.108).

Moussa (1925), after the Bennett Law and the various attempts to suppress the German language during World War I, spoke passionately about Lutheran schools:

Now for our lesson: let us become English, if we must . . . but whatever we become, let us take our parish schools with us. If the world stands another seventy-five years and our descendants delve into the distant past to read their future by their past-if there are Lutherans left that will stop to read such handwriting of God in history they will thank our German founders in one breath for the Gospel they brought to these shores, for their zeal in keeping it pure in doctrine, and for their tireless devotion in schooling it into the hearts of the young. What is it that we should have uppermost in our minds today if we thank our God for the mercies He has shown us through our fathers? This-that our fathers in holy zeal kept the Gospel pure in doctrine and schooled it into our hearts from the pulpit and from the schoolmaster's desk. (p. 351).

Two years later Moussa chaired a special committee appointed to "consider the needs and requirements . . . for its schools in the future." The committee recommended that "Every parish in our Synod should have a day school with the aim of providing eight years of instruction." The committee gave as its reason the need for a "complete system," a school system that would take children and youth from first through twelfth grade. The committee wanted Lutheran children in Lutheran schools because

the arbitrary rearrangement of grade and high school years, now in vogue in other systems, does much to make our parish schools appear misfit, as indeed they never and should never have the sole aim of conforming to other schools; but if we have a complete system of our own, all of our youth will be well served and need not fear comparisons to others. (Moussa, 1927, p.

28)

Other writers at this time defined Lutheran education by comparing it with public education. Bliefernicht (n.d.) suggested that one of the factors that brought about "an urgent need for thinking more deeply on matters pertaining to Christian education" (p. 5) was the growing efficiency of public schools. When the Germans came to this country, the Lutheran and Catholic schools they established in parishes were often superior to the local public 
schools. The Lutheran teachers and Catholic nuns were often better trained than teachers in rural public schools. But by the turn of the century, public schools had in many cases surpassed parochial schools in hiring bettertrained teachers, who employed the use of modern methods of teaching. Lutheran teachers held on to outdated methods. Bliefernicht noted, with some acerbity, that Herbartianism with its five formal steps had prevented Lutheran schools from arriving at a clearer view of a definite Christian philosophy of education: "The entire work of the [teachers] conferences dealt with this fetish, and essays, practical lessons, discussions pertaining to method, criticism of practical lessons all these revolved about this all-absorbing topic" (n.d. p. 5).

Schaller, writing some 10 years after the Bennett Law controversy, began his analysis of the struggle for Christian (Lutheran) schools with his perspective on public education:

The American public schools differ from those in Germany among other things in that they are without religion in the sense that in them none of the recognized religions is explicitly taught. Sometimes this is regarded as an advantage of the public schools, but that is making a virtue of necessity. (1910, p. 40)

He then characterized the "fight for the Christian school as a fight [for] the Christian philosophy of life" (p. 49).

When a congregation hesitates to erect a school of its own because it does not like the expenditure of so large a sum of money, it shows very clearly thereby that there is a lack of Christian knowledge which understands that this is a matter of recognizing the truth that our children belong to God and not to the world. (1900, p. 49)

Schaller feared the Lutheran school would be lost if it failed to articulate how its philosophy differed from the public school. Koehler, who was involved in the Bennett Law controversy, looked back 25 years later and sadly concluded that his church had missed the opportunity to define Lutheran education (1970).

The Depression and World War II put additional burdens on congregations that wanted to maintain their Lutheran schools. Money and teacher shortages (and in some cases oversupply) put the discussions of the philosophy of Lutheran education on hold.

In the 1940s and 1950s Lutheran writers again turned to the purpose and function of Lutheran schools, and looked for a philosophy of education that was distinctly Lutheran. The switch from German to English was complete, and the leaders and teachers in Lutheran churches were two or three generations removed from the immigrant fathers. 


\section{DESCRIPTIONS OF A LUTHERAN PHILOSOPHY OF EDUCATION}

An interesting prompt for at least one writer on the philosophy of Lutheran education was the publication of the 41 st Yearbook of the National Society for the Study of Education in 1942. The NSSE was a stronghold of progressive education at that time. The yearbook contained descriptions of various philosophies of education by a number of progressive educators, such as Mortimer Adler and William Kilpatrick, and also included a statement of the Catholic philosophy of education. But when Paul Bretschner sought permission to include a Lutheran philosophy of education, he was dismissed as too "denominational." Somewhat piqued, Bretschner (1943a) not only analyzed the other philosophical statements, somewhat critically, he also clarified his notion of Lutheran education.

In his second article Bretschner (1943b) posed the following assumptions for a Lutheran philosophy of education: First, a Lutheran philosophy of education takes into account all areas and aspects of the educative process. Second, the content of a Lutheran philosophy of education is a knowledge of principles that govern the entire process and system of education. In this point Bretschner wanted to distinguish between personal opinion and knowledge, and his emphasis was on the importance of a scientific basis for a philosophy of education. Education was to be based on sound principles of fact, reason, and research, not individual opinions. For Bretschner, however, the epistemology of Lutheran education first had to be divine revelation as found in the Bible, followed by reason and science. Bretschner also examined in this discussion the possibility of contradictions among these three sources, particularly between Scripture and reason and science. He addressed this possibility by making divine revelation primary, but he also pointed out that science, reason, and Scripture are complementary. When science and reason are used properly, they will not contradict Scripture. The concept that "All truth is God's truth," would be familiar to Bretschner.

Third, the aims and objectives of a Lutheran philosophy of education include the promotion of respect for the individual; the promotion of a faith life; the promotion of spiritual and moral life; and the promotion of physical, intellectual, and emotional life. The first goal, respect for the individual, is predicated on the scriptural emphasis on the uniqueness of each human, who possesses a soul and receives personal redemption through the life and death of Christ. The second and third aims focus on the engendering and growth of faith and the fruits of that faith in a Christian's life. The final goal emphasizes the importance of the "other" aspects of education. Bretschner, in common with most other writers on Lutheran education, refused to separate the secular from the spiritual. Such a bifurcation of secular and sacred, mathematics from catechetics, history from biblical revelation, or science from Scripture, 
is an aberration in Lutheran education. Education is a holistic activity.

Bretschner concludes his analysis somewhat plaintively: "We recognize painfully that we have left many questions unanswered and many problems unsolved" (1943b, p. 94). Such could be said of any philosophy of education.

Alan Hart Jahsmann (1960) patterned Bretschner some 17 years later. In his classic, What's Lutheran in Education, Jahsmann defined Lutheran educational philosophy as "Biblical theology and Lutheran thinking applied to education" (1960, p. xi). He wrote his book because, "To date no thorough systematic theoretical study of Lutheran education has been published, either from a theological, philosophical, or from an educational point of view" (1960, p. xi). He modestly suggested that his text would serve until a recently appointed committee of his church completed its work.

Jahsmann (1960) began by describing 16 theological principles that determine objectives. These principles are fundamental truths of Scripture, (e.g., there is a personal God who is triune, and the only sure norm of religion, knowledge, and truth is the Bible). Second, he demonstrates how these principles have implications for educational objectives. The following educational objectives are what he saw as a Lutheran philosophy of education:

- Children belong first of all to God-not to parents, not to the organized church, not to the state.

- The first and final purpose of all education ought to be the glorifying of God.

- The first concern of Lutheran education must always be the leading of people to a conviction of sin and to a personal faith in Jesus Christ as the Lamb of God who takes away the sin of the world.

- Lutheran education must have as its primary purpose the preaching and teaching of the gospel.

- Sanctification, the total Christianizing of the individual, is the goal of Christian education.

- The power to live a Christian life is Christian faith that expresses itself in love of God and love of people.

- The young are to be trained to fulfill specific services of Christ and to participate in the life and work of the church. (1960, pp. 8-10)

Jahsmann (1960) goes on to examine the objectives and goals of Lutheran education; the responsibilities and rights of parents, church, and state in education; the means, the students, and the methods to be used in education; the function of relationships; and, finally, the various agencies of Lutheran education.

No one wrote as well or as thoroughly as Jahsmann on the meaning and function of Lutheran education. The committee of which he spoke never produced anything near to what Jahsmann did. But Lutherans still seem to be searching for the best exposition of a philosophy: Forty years after Jahsmann's book, Rietschel (2000) repeated Jahsmann's complaint verbatim: 
"No thorough systematic theoretical study of Lutheran education has been published" (p. 45). Perhaps that seemingly endless search for a final statement of philosophy is a good thing. Final, definitive statements of a philosophy tend to have two negative effects. They harden into cement and people stop thinking about what is important. And they also can distract people from going where they ought to go to find answers to living and learning: God's Word.

\section{THE CONGREGATIONAL FOCUS OF LUTHERAN EDUCATION}

Regardless of whether there will be a final statement of what Lutheran education is, Lutherans have always held the view that Lutheran schools are parish schools. Lutheran education, as it is practiced in a formal setting, is a parish or congregational activity. The church and the parochial school are and were inseparable. Stephen Schmidt (1972) described the Lutheran school of years ago:

School was often interrupted by church activities. For example, when the church bell tolled, youngsters knew that in a day or so they would be singing for a funeral, accompanying their teacher to the church to add comfort to the bereaved relatives. Church also became the focus of the formal school lessons. Music was not only for school or for enjoyment, but in preparation for the worship services on Sunday. . . Religious instruction in school led to the church's rite of confirmation, where careful examination in front of the entire parish community was held so that the children could prove their learning. Parents and congregation rejoiced annually over the excellent answers of the young Lutherans. Purity of doctrine was again passed to another generation of congregation members. (pp. 54-55)

Coiner (1954) discussed this congregational responsibility first by examining Old Testament examples where the people of Israel took responsibility for the instruction of children (Joshua 8:35). More directly, however, Coiner saw the congregational responsibility for Christian education of children as flowing from Christ's command to teach all nations. While never minimizing parental responsibilities, many Lutheran writers in past and present urged congregations to establish and maintain Lutheran schools, and the support of such schools is a congregational responsibility. Schaller (1900) was typical of these writers: "therefore, the Christian congregation, quite aside from this general duty of spreading the word of the Gospel, owes it as a duty of true charity to furnish opportunities for Christian education by establishing parochial schools" (p. 2). Those church bodies that still maintain a school system often had in the years they were organizing either a requirement for membership or at least a strong admonition that prospective congregations 
establish and maintain a Lutheran school (see Stellhorn, 1963).

Today, the overwhelming majority of Lutheran schools have a congregational setting. Parental associations have started at some schools, and several congregations are operating an increasing number as joint schools. Tuition, once charged only to those who were not members of the congregation, now is charged to all children in most congregations. But there still is a strong belief that a school should have a congregational base, that the congregation's children should be in that school, and that all members of the congregation should contribute to the operation of the school. There are congregations that, on the extension of that principle, charge no tuition to any children.

\section{TEACHERS}

A system of elementary and secondary schools such as that operated by Lutherans requires qualified teachers who are committed to the philosophy and purpose of those schools. The Lutheran German immigrants established institutions for training teachers almost as soon as they landed on U.S. soil. These institutions, which have now become colleges and universities, continue to produce teachers for Lutheran elementary and secondary schools. There is, however, a shortage of teachers who have been trained in church-sponsored and partially church-supported colleges and universities. Lutheran schools have had to employ teachers trained in public colleges and universities. These teachers are variously termed nonrostered or noncertified staff. Such teachers, although professionally trained and qualified, may not always share the viewpoints concerning Lutheran education as those who have had their training within the Lutheran school system.

This concern has prompted Lutheran church bodies to intensify recruitment efforts for their colleges and universities. Church bodies are also taking steps to identify areas of dissatisfaction that may cause teachers in Lutheran schools to resign, thus exacerbating the teacher shortage. One recent survey (Commission on Ministerial Growth and Support, 1999) identified eight variables that predict whether or not a teacher is satisfied in a Lutheran school: 1) whether the teacher has a supportive relationship with the administration of the school, 2) whether the teacher has a good working relationship with other teachers, 3) the teacher's perception of the adequacy of his or her pay and benefits, 4) the teacher's perception of his or her effectiveness as a teacher, 5) the wholesomeness of the relationship between the school and congregation, 6) the level of distress the teacher has in teaching, 7) the opportunities the teacher has for continuing education, and 8) whether or not the teacher has tenure.

With some adjustment for wording, these reasons are quite similar to national surveys of teachers in public schools. In fact, some studies comparing turnover between public and private schools show private schools experi- 
encing greater turnover rates than public schools (Ingersoll, 2001). Lutheran church bodies are not always sure what needs to be done to provide an adequate supply of qualified teachers, qualified both professionally and in terms of the philosophy of Lutheran education. Lutherans agree, however, that without such teachers, Lutheran schools may not survive.

\section{LUTHERAN SCHOOLS TODAY}

The descendants of these Lutheran immigrants (and the hundreds of thousands of others who have joined these churches) are distributed into several different church groups, some of which still use a somewhat archaic term, synod. The origins of these church bodies can be traced to the different nationalities that came to this country, including the Swedes, the Norwegians, the Germans, the Danes, the Finns, and others. For some 200 years, these church bodies have joined, separated, amalgamated, disappeared, and reappeared with other names until currently there are 12 Lutheran denominations in the United States. Two-thirds of the Lutherans in the U.S. belong to a Lutheran church (Evangelical Lutheran Church in America) that had its roots in the Scandinavian immigration. Congregations in this church body are much less likely to have Lutheran schools. The other one-third of Lutherans belong to church groups which for the most part have a German heritage and the congregations in these churches tend to have both elementary and secondary Lutheran schools. Lutheran churches operate a Lutheran school system that enrolls nearly 250,000 students. In 1999-2000 there were 1,514 elementary and 81 secondary schools operated by Lutherans, enrolling 194,000 at the elementary level and 19,500 in high schools. There were 14,300 teachers in these schools. This enrollment constitutes $4 \%$ of the total private, religious-oriented school enrollment (Broughman \& Colaciello, 2001).

\section{LUTHERAN SCHOOLS OF TOMORROW}

A long-time observer of Lutheran education, Carl Moser (2001), speculates on the changes and challenges facing Lutheran schools in the 21 st century. Lutheran schools are enrolling increasing numbers of children who are not members of the congregation that supports the school. Non-Lutheran children now make up $95 \%$ of the enrollment in some Lutheran schools (Moser, 2001). Many of these families are unchurched or nominally churched, and the school provides the opportunity to show these children the saving truths of Scriptures. Lutheran schools have moved from ensuring the faith of Lutheran children (S. Schmidt, 1972) to reaching out with the gospel to the unchurched. But this also raises questions whether Lutheran schools should have a curriculum and a philosophy of education that are distinctly Lutheran when most of the children enrolled are not Lutheran. 
Where once students of Lutheran schools were primarily Caucasian of northern European heritage, there is an increased diversity in language and culture in Lutheran schools today. Although this diversity does not yet reflect the same proportions in American society, Moser's numbers indicate that $17 \%$ of the students in Lutheran schools are non-White: African Americans, Hispanics, Asian, and other races. If there is a language heard today in Lutheran schools that is not English, it is most likely Spanish.

Lutherans, together with other churches, have discovered the potential of early childhood education. The growth of preschools or childcare centers in Lutheran churches has been dramatic. One Lutheran church group reported a fourfold increase in the preschool enrollments over a 10-year period. Over $60 \%$ of the children enrolled were not from the sponsoring congregation. Many Lutheran congregations see the preschool as a particularly important means of reaching out to the unchurched with the gospel.

Accountability has come to Lutheran schools. Lutheran teachers are licensed by the state; Lutheran schools meet graduation standards in states that require them; many Lutheran schools are involved in the same highstakes testing as is found in public schools; and Lutheran schools are being accredited by national, state, or denominational agencies. Not everyone sees this accountability as a positive influence on Lutheran education. Moser (2001) suggests that one ill effect of the administrative responsibility accompanying this accountability is that the job of principal is less attractive.

This accountability can also imply or encourage a sense of distrust among parents, teachers, and members of the congregation. The words and actions of a teacher are no longer unquestioned by parents and the cooperation between home and school previously seen in the rural Lutheran school is a thing of the past.

Funding of Lutheran schools continues to be a challenge for congregations. As tuition charges increase for both members and nonmembers, the concern is that Lutheran schools will become elite private institutions for the wealthy. Lutherans also tend to embrace a myriad of positions on the issues of government aid and vouchers. The Bennett Law may be forgotten by most Lutherans, but the fierce independence that impelled the Germans to defend their schools remains in their American descendents. Many Lutherans worry that increased government aid will affect the ability of Lutheran schools to have an education that is distinct from public education. Rietschel urges "scrutiny" (2000, p. 134).

Lutheran schools in the 21 st century will continue and strengthen their family-oriented emphasis. A fundamental tenet of Lutheran education is that children belong, after God their creator, to parents (Jahsmann, 1960). Teachers in Lutheran schools are uncomfortably aware that parents may have the impression that the Lutheran school has taken over the spiritual responsibility for their children. Whether parents have this impression because they 
wish to believe it or because the school has encouraged this view is immaterial. Whatever the source, the belief that the Lutheran school can carry out Christian education apart from the family is a very bad idea. Lutheran schools are reaching out to parents by involving them more in the operation of the school and in the setting of school policies. Schools are involving parents by taking seriously the issues of accountability. Schools are encouraging family involvement in curriculum issues and school activities. One church body has recently completed a comprehensive religion curriculum that includes infants through high school youth. An important feature of each lesson in that curriculum is the explicit inclusion of material that allows parents to use that lesson in the home. The Bennett Law debate may have been seen as a battle for parental rights in terms of the language that children should speak, but Lutheran schools of the 21 st century have a better view of parental rights: the right and responsibility of parents to guide and direct the spiritual life of their child. And the Lutheran school is there to help them accomplish this goal.

\section{CONCLUSION}

This discussion of a parochial or a religious school system ought not obscure the real issue. Church bodies that operate schools for the $14 \%$ of the children of the United States who do not attend public schools know that their churches do not exist for the operation of these schools, as important as these schools are to the children who attend, to the parents who send their children, and to the parishes that sacrifice to maintain them. The agency or means through which a church carries out its mission is important, but not as important as the mission. The church is the communion of saints, the forgiven sinners whose one goal is to share the good news throughout the world about the life and death of Christ, His birth and resurrection, His incarnation and ascension, His beginning in eternity, and His rule into eternity. That Christ came to live and die for every person who ever lived or who will live. That sinless Christ took our sin and condemnation so we might have the righteousness of God and live with Him in eternity. This is a simple message and it is the church's message to proclaim to all. The school is one way in which this message is shared, but it is only one way.

Sometimes churches, teachers, children, parents, and pastors can become consumed with the process of education. The careful training of teachers, the exquisite design of curriculum and materials, the careful elucidation of teaching methodology, the endless assessment and diagnosis of the learners, and long essays such as this can distract us from what is really important; and we miss the miracle. To prosper and succeed in the third millennium of Christianity, Lutheran schools, like all private, religious schools, must stay focused on their spiritual purpose and mission. 


\section{REFERENCES}

Beck, W. (1931/1965). Lutheran elementary schools in the United States. St. Louis, MO: Concordia.

Bliefernicht, E.R. (n.d.). The establishment of educational policies in our synod, with special emphasis on the Christian day-school. Unpublished essay presented to the Milwaukee Teachers Conference.

Bretschner, P. (1943a). Toward a Lutheran philosophy of education, Part I. Concordia Theological Monthly, 14, 8-33.

Bretschner, P. (1943b). Toward a Lutheran philosophy of education, Part II \& III. Concordia Theological Monthly, 14, 81-94.

Broughman, S., \& Colaciello, L. (2001). Private school universe survey: 1999-2000. Washington, DC: US Department of Education.

Burtchaell, J. T. (1998). The dying of the light. Grand Rapids, MI: Eerdmans.

Coiner, H. G. (1954). The scriptural basis for the responsibility of the Christian congregation in Christian education. Lutheran Education, 89, 395-399.

Commission on Ministerial Growth and Support: LC-MS. (1999). Teaching 2000 Survey: Phase I \& II. Houston, TX: Opinions UnLimited, Inc.

Fredrich, E. (1992). The Wisconsin synod Lutherans. Milwaukee, WI: Northwestern.

Hamre, J. (1965). Georg Sverdrup's defense of secular education. The Lutheran Quarterly, 16, 43-50.

Hamre, J. (1995). Georg Sverdrup: Church-state relations and the public schools. Concordia Historical Institute Quarterly, 68, 151-165.

Ingersoll, R. (2001). Teacher turnover and teacher shortages: An organizational analysis. American Educational Research Journal, 38, 499-534.

Jahsmann, A. H. (1960). What's Lutheran in education. St. Louis: Concordia.

Koehler, J. P. (1970). The history of the Wisconsin synod. St. Cloud, MN: Sentinel Publishing Company.

Madson, N. (n.d.). The Norwegian synod and the Christian day-school. Privately published.

Moser, C. (2001) Change!!??: Reflections on Lutheran schools at the dawn of the millennium. Lutheran Education, 137, 131-141.

Moussa, H. K. (1925) Seventy-five years of the Wisconsin Synod in brief survey. The Northwestern Lutheran, 12, 338-351.

Moussa, H. K. (1927). Report of the special committee on education made to the synodical committee. Synodical Proceedings, 26-32.

Rietschel, W. (2000). An introduction to the foundations of Lutheran education. St. Louis: Concordia Academic Press.

Schaller, J. (1900). The need of Christian education by means of parochial schools. Paper presented at the Michigan Teachers Conference, Bay City, MI.

Schaller, J. (1910). The struggle for Christian schools as a struggle for the Christian philosophy of life. Paper presented at the Milwaukee Conference.

Schmidt, S. (1972). Powerless pedagogues. River Forest, IL: Lutheran Education Association.

Schmidt, W. (1968). Wisconsin Synod Lutheran parochial schools: An overview of the years 1850-1890. Unpublished doctoral dissertation, University of Wisconsin, Madison.

Stellhorn, A. (1963). Schools of the Lutheran church-Missouri synod. St. Louis, MO: Concordia.

Ulrich, R. J. (1980). The Bennett Law of 1889: Education and politics in Wisconsin. New York: Arno Press.

John Isch teaches at Martin Luther College. His areas of specialty are the history and philosophy of education, psychology, and research. Correspondence concerning this article should be addressed to Dr. John Isch, Martin Luther College, 1995 Luther Court, New Ulm, MN 56073. 
Copyright of Catholic Education: A Journal of Inquiry \& Practice is the property of Catholic Education: A Journal of Inquiry \& Practice and its content may not be copied or emailed to multiple sites or posted to a listserv without the copyright holder's express written permission. However, user's may print, download, or email articles for individual use. 